\title{
Cultural aspects of play. Implications for the psychological evaluation and therapy of children diagnosed with autism spectrum disorder
}

\author{
Aspecte culturale ale jocului. Implicaţii în evaluarea psihologică şi terapia \\ copiilor diagnosticaţi cu tulburări din spectrul autist \\ Raluca Cristina VĂRĂŞTEANU ${ }^{1}$, Cezarina Daniela Stănescu BOȚAN ${ }^{1}$, \\ Raluca Dafina IONUȚIU2, Andrei KOZMA ${ }^{3,4,5}$ \\ ${ }^{1}$ Cercetare în Sănătate Mintală, INSMC „Alessandrescu-Rusescu“, Bucureşti \\ ${ }^{2}$ Centrul de Sănătate Mintală, INSMC „Alessandrescu-Rusescu“, Bucureşti \\ ${ }^{3}$ Laboratorul de Studii şi Cercetări în Pediatrie şi Obstetrică Socială, \\ INSMC „Alessandrescu-Rusescu“, Bucureşti \\ ${ }^{4}$ Academia de Ştiințe Medicale din România \\ ${ }^{5}$ Academia Oamenilor de Ştiință din România
}

\begin{abstract}
Children's play has an essential role in their cognitive, social and emotional development. From simple object manipulation and functional exploration, to symbolic and role play, these play activities have been observed across all societies and can be considered a universal feature of human psychology, with a specific cultural imprint.

Beyond cultural variations, the characteristics of play provide insights about the development level and about the mechanisms of symbolic thinking. Play tasks are included in diagnostic and development assessment tools, especially in the evaluation of children with autism spectrum disorders (ASD). Also, play is an important part of the therapeutic intervention for children and their families.

This paper aims to explore changes in play after intervention for two children, diagnosed with ASD, included in the Early Intervention Project, developed by CCSM. The method used was observational analysis of play sequences, selected from the Symbolic Play Test (Lowe $\mathcal{E}$ Costello, 1976). Results show a significant improvement in play functionality, complexity, expressing and sharing of emotions and verbalization. However, some ASD specific difficulties such as repetitive behaviors, echolalic speech, social interaction deficits persist.

Integrating play as part of therapeutic interventions can lead to additional benefits for children with $A S D$, at both cognitive and socio-emotional level.
\end{abstract}

Keywords: play, autism spectrum disorder (ASD), evaluation and therapy 


\section{REZUMAT}

Jocul are un rol esențial în dezvoltarea cognitivă, socială si emoțională a copilului. De la jocul simplu de manipulare şi explorare funcțională până la jocul simbolic şi de rol, acesta a fost observat in toate societățile, putând fi considerat o trăsătură universală a psihologiei umane, dar cu amprenta specifică contextului cultural.

Dincolo de variațiile culturale, caracteristicile jocului oferă informații referitoare la nivelul de dezvoltare şi de funcționare a mecanismelor gândirii simbolice. Jocul este inclus ca parte a unor instrumente de evaluare a dezvoltării şi de diagnostic, mai ales în evaluarea copiilor cu particularități din spectrul autist (TSA). De asemenea, jocul reprezintă o parte importantă a intervenției terapeutice adresate copiilor şi familiilor acestora.

Obiectivul lucrării de față constă în explorarea evoluției jocului în urma intervenției la doi copii diagnosticați cu TSA, din cadrul proiectului de intervenție timpurie desfăşurat de CCSM. Metoda folosită a fost analiza observațională a unor secvențe de joc selectate din Symbolic Play Test (Lowe E Costello, 1976). Rezultatele obținute indică o îmbunătățire semnificativă la nivelul jocului, în ceea ce priveşte funcționalitatea, complexitatea, exprimarea, împărtăşirea emoțiilor şi apariția verbalizării. Cu toate acestea, se mențin unele dificultăți specifice TSA - stereotipii, ecolalie, deficite de interacțiune socială.

Includerea jocului ca parte a intervenției terapeutice poate aduce beneficii suplimentare pentru copiii diagnosticați cu TSA, atât la nivel cognitiv, cât şi socio-emoțional.

Cuvinte cheie: joc, tulburări din spectrul autist (TSA), evaluare şi terapie

\section{INTRODUCERE}

În ultimele decenii, se constată o proliferare importantă a cercetărilor care își propun să contribuie la înțelegerea funcționării copiilor cu tulburări din spectrul autist (TSA). Creșterea prevalenței acestui diagnostic justifică preocuparea constantă pentru a dezvolta strategii de intervenție și pentru a înțelege aspecte legate de eficacitatea acestora. Jocul prezintă o importanță centrală pentru dezvoltarea tuturor copiilor, iar deficitele la nivelul jocului copiilor cu TSA sunt destul de bine evidențiate în literatura de specialitate. Cu toate acestea, jocul a fost mai puțin utilizat în intervențiile adresate copiilor diagnosticați cu TSA [1]. Fără dobândirea unei înțelegeri mai profunde a dificultăților cu care copiii se confruntă în joc, cercetătorii și clinicienii nu pot dezvolta și implementa strategii eficiente care să se adreseze acestei componente.

Jocul este o formă de manifestare întâlnită la toți copiii, indiferent de rasă, apartenență etnică sau confesională, cultură etc., care le satisface în cel mai înalt grad nevoia de activitate, generată, la rândul ei, de trebuințele, dorințele și tendințele specifice vârstei [2]. De asemenea, activitățile de tip ludic reprezintă acțiuni specifice, fără utilitate imediată, sunt generatoare de dispoziții emoționale pozitive, creează revigorare, sentimente de plăcere și bucurie [3].

Jocul este transcultural și social și, deși se întâlnesc diferențieri în formele de manifestare, transferurile ludice dintr-o cultură în alta au fost posibile și datorită structurii comune date de limbajul universal și de funcțiile pe care acesta le are. Jocul este o constantă a vieții sociale, cu puternice valențe formative, socializatoare [4].
Piaget susține că jocul este o expresie a procesului de asimilare, în care copilul încearcă să înțeleagă lumea din jur și să o schimbe pentru a corespunde propriei înțelegeri și experiențe [5]. Jocul reprezintă o interacțiune dinamică între copil și mediu [6], se manifestă prin comportamente observabile și experiența internă pozitivă asociată acestora [7]. Jocul, în general, contribuie la dezvoltarea cognitivă, emoțională și a personalității. El oferă un mijloc de explorare a diverselor roluri și reguli sociale, precum și de găsire a soluțiilor la probleme, promovând creativitatea și imaginația. De asemenea, reprezintă contextul pentru exersarea autoreglării emoționale și pentru întărirea realațiilor de atașament.

De-a lungul ontogenezei sale, copilul trece prin mai multe stadii de dezvoltare văzute prin prisma jocului. În primele 12 luni de viață, copilul explorează și manipulează fizic obiecte prin atingere, scuturare, aruncare, lovire, învățând despre forme, culori, mărimi și texture (joc de explorare). Cu timpul, copilul incepe să manipuleze jucăriile în așa fel încât să obțină rezultatul dorit, învățând despre consecințele acțiunilor sale și căpătând simțul controlului asupra obiectelor din jur (joc de tip cauză-efect). Începând cu al doilea an, se manifestă mai activ jocul de construcție (tip puzzle, lego, modelare din plastilină). Un rol important îl are și jocul fizic, care ajută la dezvoltarea abilităților motorii grosiere, oferind, în același timp, șansa de a interacționa cu ceilalți și cu obiectele din mediul înconjurător. Pe masură ce copilul învață să folosească adecvat jucăriile, în funcție de scopul pentru care au fost create, se conturează jocul funcțional (de exemplu, aruncarea unei mingi, împingerea unei mașinuțe etc.). Tot în jurul vârstei de 2 ani, copilul începe să dobândească capacități de repre- 
zentare simbolică, fiind capabil să-și utilizeze imaginația pentru a pretinde că lucrurile sunt cu totul altceva decât ceea ce reprezintă în realitate (jocul simbolic), astfel că un băț fluturat în aer este o sabie, dar, călărit, devine un cal sau o bucată de țeavă este folosită ca stetoscop, iar în momentul următor devine șarpe. În cadrul acestui tip de joc, este inclus și jocul de rol.

Jocul simbolic este cea mai complexă formă de joc, care apare mai târziu în ontogeneză, fiind deosebit de important pentru dezvoltarea abilităților sociale, a limbajului și comunicării. Acesta oferă copilului șansa de a compensa ce nu îi oferă realitatea, fantezia servind drept substitut pentru lumea reală. în cadrul acestuia, copiii au șansa de a-și dezvolta imaginația, învață să-și confrunte problemele emoționale și să încerce să se pună în acord cu ele. De asemenea, pot găsi modalități de a interacționa cu alții de dragul unui scop comun. Jocul simbolic este văzut ca un comportament simulativ sau nonliterar, un mod de acțiune „ca și cum", folosind ceva ce în realitate nu este așa.

Conform concepției piagetiene, simbolizarea apare în stadiul dezvoltării senzoriomotorii, pe măsură ce crește distincția între semnificant (obiectul/acțiunea prezentă) și semnificat (obiectul/acțiunea absentă). În cadrul jocului, simbolizarea trece prin mai multe etape de dezvoltare: decentrarea sau trecerea de la sine ca agent al acțiunii la implicarea celuilalt în ,jocul de-a...", decontextualizarea, care reprezintă trecerea de la folosirea obiectelor reale/realiste la obiecte imaginate în „jocul de-a..." și integrarea care se referă la combinarea acțiunilor imaginare în secvențe) [5].

Conform clasificării ICD 10 [8], tulburarea de spectru autist este caracterizată prin deficite persistente în capacitatea de inițiere și de susținere a interacțiunii sociale reciproce și a comunicării sociale, precum și de o serie de tipare de comportament și interese restrânse, repetitive și inflexibile.

Mai multe abordări terapeutice au fost dezvoltate pentru a îmbunătăți interacțiunile sociale și abilitățile de joc la copiii cu TSA. Aceste abordări includ antrenarea copilului cu TSA în joc, identificarea abilităților și intereselor individuale de joc, precum și dezvoltarea unor interacțiuni și contexte de relaționare adecvate. Intervențiile focalizate pe grup reprezintă cel mai amplu tip de intervenție socială pentru copiii cu TSA [9]. Intervenția este, de asemenea, centrată pe familie, în special la copiii mai mici [10]. Cercetările au pus în evidență îmbunătățiri semnificative ale comportamentului social la copiii diagnosticați cu TSA, atunci când interventia este centrată pe adaptarea modului de interacțiune a părintelui la stadiul de dezvoltare în care se află jocul copilului [11]. Pentru acești copii, îmbunătățirea abilităților de joc duce la dezvoltarea interacțiunilor sociale pozitive, precum și la scăderea comportamentelor neadecvate [12].
Din perspectiva caracteristicilor jocului la copiii cu tulburări din spectrul autist, numeroase studii au relevat faptul că jocul acestora diferă de cel al copiilor cu întârziere în dezvoltare sau al celor cu dezvoltare tipică [13]. Acesta a fost descris ca fiind restrâns și repetitiv, implicând răspunsuri stereotipe și ca fiind lipsit de complexitatea și diversitatea care caracterizează jocul copiilor fără TSA [14]. Aceste caracteristici de joc au făcut parte din criteriile de diagnostic pentru autism timp de mai mulți ani, dar nu sunt enumerate în cea mai nouă ediție a „Manualului de diagnostic și statistică a tulburărilor mintale“ (DSM-5) [15].

\section{OBIECTIVE}

Lucrarea de față își propune să exploreze evoluția jocului în urma intervenției terapeutice la copiii diagnosticați cu TSA incluși în proiectul de intervenție timpurie desfășurat de Colectivul de Cercetare în Sănătate Mintală din cadrul Institutului Național pentru Sănătatea Mamei și Copilului „Alessandrescu-Rusescu“, București.

\section{METODĂ}

În cadrul studiului de față, s-a folosit metoda studiului de caz, în care s-au realizat analize observaționale ale specificului jocului pre și postintervenție. Din lotul clinic, au fost selectate cazurile a doi copii, care vor fi prezentate în cele ce urmează. Pentru a putea realiza comparații relevante între particularitățile jocului în cele două momente, am ales o situație standard de joc din Symbolic Play Test [16]. Acesta este un instrument de evaluare a activităților de joc nonverbale spontane într-o situație structurată, ce constă în patru situații independente, în care copilului i se oferă într-o manieră standard obiecte în miniatură pe care poate să le folosească în mod liber.

\section{REZULTATE}

Primul studiu de caz este reprezentat de Robert, în vârstă de 2 ani și 5 luni, diagnosticat cu TSA și tulburare hiperkinetică. În evaluarea preintervenție, s-a înregistrat un scor 36 (comportament ușor autist) la testul CARS (The Childhood Autism Rating Scale) [17], scor 9 (ceea ce indică TSA) la testul ADOS (Autism Disorder Observation Schedule) [18] și un coeficient de dezvoltare (Q.D.) de 70 evaluat cu scalele Bayley (Bayley Scales of Infant and Toddler Development) [19]. Evaluarea limbajului a sugerat un nivel de dezvoltare al limbajului expresiv corespunzător vârstei de 11 luni și un nivel al limbajului receptiv corespunzător vârstei de 10 luni. Copilul a fost expus la ecrane în mod prelungit încă de la 8 luni, câte 3-4 ore pe zi. În urma evaluării, la 
nivelul jocului s-au constat elemente atipice, jocul fiind repetitiv, nestructurat, preponderent explorator, prin manipulare fizică a obiectelor, având interes restrâns pentru jucării (preferințe pentru cifre și litere) și pentru interacțiune, capacitate scăzută de imitație, contact vizual satisfăcător, cooperare pe termen scurt. La momentul evaluării inițiale, Robert nu prezenta joc funcțional, expresivitatea emoțională fiind redusă, observațiile repetate evidențiind o dispoziție tristă marcantă. În intervenție, au fost folosite tehnici comportamentale, terapie prin joc, meloterapie, stimulare cognitivă, logopedie. Copilul a beneficiat de un număr de 153 ședințe în 2,5 ani de terapie, frecvența întâlnirilor fiind de două ori pe săptămână în sesiuni individuale și de o ședință pe săptămână în sesiune de grup.

Evaluarea postintervenție s-a realizat la vârsta copilului de 4 ani și 11 luni și s-au înregistrat următoarele scoruri: CARS - scor 30, ADOS - scor 8, Q.I. - 80 (Stanford-Binet Intelligence Scale) [20]; limbaj receptiv corespunzător vârstei de 3 ani și 9 luni. Aceste scoruri indică un progres semnificativ al copilului în toate ariile de dezvoltare.

Rezultatele analizei observaționale arată următoarele: Robert poziționează obiectele prin raportare potrivită unele față de altele, acțiunile din timpul jocului sunt orientate spre obiecte mai degrabă decât spre sine, jocul este acompaniat de verbalizări descriptive adecvate. Copilul manifestă entuziasm și își împărtășește emoția cu observatorul, verifică reacția adultului, are contact vizual bun, solicită atenția adultului, indică cu degetul și verbal, integrează secvențe de joc cu sens, introduce spontan elemente noi în joc. Jocul simbolic este prezent, prin substituirea obiectului și imaginarea prezenței unui obiect absent. Se mențin repetiția, stereotipiile gestuale, intonația ușor particulară în timpul verbalizării, unele structuri fixe în exprimare.

Al doilea studiu de caz se referă la Ana, în vârstă de 3 ani, diagnosticată cu TSA, întârziere ușoară în dezvoltarea psihomotorie, hipoacuzie bilaterală medie, protezată la 3 ani și 4 luni. La evaluarea preintervenție, s-au înregistrat următoarele date: CARS - scor 37,5, ADOS - scor 10, Q.D. - scor 67 (Scalele Bayley), limbaj expresiv și receptiv dezvoltat corespunzător vârstei de 1 an și 5 luni. Ana a fost expusă prelungit la ecrane (TV și Smartphone) de la vârsta de 8 luni, câte 5-6 ore pe zi. La momentul evaluării inițiale, jocul este caracterizat prin elemente atipice, este repetitiv, centrat pe sine, nestructurat. Tipul jocului este preponderent de construit, cu elemente de joc simbolic incipient. Copilul manifestă interes restrâns pentru jucării și interacțiune, capacitate scăzută de imitație, contact vizual deficitar, cooperare pe termen scurt, dorință de control asupra jocului.

Intervenția a constat în tehnici comportamentale, terapie prin joc, meloterapie, stimulare cognitivă, logopedie (216 ședințe, timp de 2,5 ani).
Evaluarea postintervenție, la vârsta de 5 ani și 4 luni, a relevat următoarele scoruri: CARS - scor 30, ADOS - scor 10, Q.I. (Stanford-Binet) - scor 56, limbaj expresiv corespunzător vârstei de 2 ani și 6 luni, iar receptiv la nivel de 3 ani și 6 luni. În ceea ce privește jocul, copilul preferă activități repetitive, jocuri simple de tip cauză-efect, manifestă interese restrânse, integrează din memorie în jocul cu personaje scenarii cu dialoguri în limba engleză.

Rezultatele analizei observaționale au indicat următoarele: Ana poziționează obiectele prin raportare potrivită unele față de altele, dar cu orientare externă (nici spre personaj, nici spre propria persoană); jocul este acompaniat de verbalizări cu caracter repetitiv, preponderent în limba engleză, sunt prezente stereotipii verbale și ecolalie întârziată. De asemenea, Ana repetă secvența de joc, folosește intonație particulară în timpul verbalizării, prezintă expresivitate emoțională scăzută, jocul este funcțional, manifestă interes față de obiecte, dar nu și față de interacțiune, iar contactul vizual este deficitar.

\section{DISCUȚII}

Rezultatele acestui studiu arată că, în urma intervenției terapeutice, ambii copii au prezentat îmbunătățiri la nivelul jocului, în ceea ce privește cooperarea, implicarea și interesul față de jucării și activități de joacă, flexibilizarea față de implicarea unei alte persoane în joc, contactul vizual, complexitatea acțiunilor, a scenariului, adecvarea verbalizărilor la tema/subiectul jocului. De asemenea, se remarcă dezvoltarea generală a limbajului, atât al celui expresiv, cât și al celui receptiv și a funcționalității acestuia. Este important de menționat faptul că ambii copii erau neverbali la momentul inițierii terapiei. Evaluarea finală indică o creștere în capacitatea de exprimare și împărtășire a emoțiilor și îmbunătățiri la nivelul atenției împărtășite. $\mathrm{Cu}$ toate acestea, s-au menținut anumite dificultăți specifice TSA, cum ar fi stereotipiile (gestuale, verbale etc.), tendința spre repetiții, centrarea pe propria persoană în orientarea acțiunilor din timpul jocului, nivelul deschiderii/respingerii interacțiunii în joc.

O analiză comparativă a diferențelor între scorurile obținute de cei doi copii evidențiază faptul că cei doi copii au avut o evoluție diferită. Cazul Robert a cunoscut o evoluție spectaculoasă la nivelul tuturor ariilor de dezvoltare, în timp ce cazul Ana a prezentat o evoluție nonliniară. Factorii care pot fi considerați relevanți pentru evoluția diferită a copiilor sunt: nivelul cognitiv general, comorbiditatea, gradul de afectare TSA, nivelul de afectare a funcționalității, factori familiali (implicarea în terapie, percepția asupra dificultăților copilului, acceptarea diagnosticului, istoricul părinților, stilul parental, tipul atașamentului). Includerea unei compo- 
nente bazate pe joc în programul terapeutic livrat în cadrul proiectului de intervenție timpurie adresat copiilor cu TSA a adus beneficii suplimentare funcționării acestora. Un câștig major ar consta în crearea unui context de învățare prin activități care sunt recompensatoare prin ele însele și aceasta se observă în funcționalitatea copilului.

În intervenția noastră, am utilizat jocul ca bază a strategiei terapeutice pentru a facilita dezvoltarea de abilități si exprimarea emoțională, în mod special atunci când copiii nu au abilitățile verbale și cognitive necesare pentru a-și exprima gândurile și sentimentele. Astfel, jucăriile țin loc de cuvinte, iar acțiunile de joc au valoare de comunicare [21]. De asemenea, jocul a reprezentat contextul în care copiii au învățat răspunsuri adaptative, au exersat comportamente funcționale, chiar dacă prezentau deficite la nivelul competențelor emoționale și sociale. Nu în ultimul rând, interacțiunile pozitive dintre terapeut și copil, care au luat naștere în cadrul jocului, au contribuit la formarea unei relații de siguranță și încredere între adult și copil, element atât de relevant pentru dezvoltarea armonioasă a copilului și pentru o evoluție favorabilă în terapie.

Există diverse terapii prin joc folosite în lucrul cu copilul cu dizabilități, care au beneficii semnificative asupra structurării sinelui afectiv, motivațional, cognitiv și social al copilului în cauză [22].

\section{CONCLUZII}

Jocul ocupă un rol deosebit în abordarea terapeutică a copilului. Caracterul universal și interactiv al jocului îi permite terapeutului să adapteze tehnicile folosite la specificul nevoilor fiecărui copil și la dificultățile cu care acesta se confruntă. Terapia centrată pe joc ii oferă specialistului posibilitatea de a pătrunde în lumea copilului. Totodată, prin joc, copilul se poate exprima liber și în ritm propriu, cu asigurarea că va fi înțeles și acceptat.

Studiul nostru confirmă faptul că jocul se dovedește a fi o metodă eficientă în procesul de intervenție și în cazul copiilor diagnosticați cu TSA. În acest context, subliniem rolul esențial al jocului, nu doar în abordările terapeutice, cât și în interacțiunile cotidiene dintre părinți și copii.

\section{Notă}

Toți autorii au contribuție egală cu cea a primului autor.

Conflict of interest: none declared Financial support: none declared

\section{REFERENCES}

1. Wolfberg PJ. Play and imagination in children with autism. Teachers College Press, 2009.

2. Osadici R. Jocurile de copii tradiţionale. Aspecte ale funcţiei formative. The Journal of Ethnology and Culturology (Chisinau) 2016;20.

3. Huizinga J. Homo ludens. Ed. Humanitas, Bucureşti, 1998.

4. Bădescu I, Cucu-Oancea O, Siseştean Gh. Tratat de sociologie rurală. Ed. Mica Valahie, Bucureşti, 2009.

5. Piaget Jean. Psihologia inteligenţei. Ed. Cartier, Chişinău, 2008.

6. Sutton-Smith B. Children's play: some sources of play theorizing. New Directions for Child and Adolescent Development, 1980.

7. Parham LD, Fazio LS. Play in occupational therapy for children (2nd ed.). Mosby, St. Louis, MO, 2008.

8. Organizația Mondială a Sănătății. ICD-10 Clasificarea tulburărilor mentale şi de comportament. Descrieri clinice şi îndreptare diagnostice. Ed. Trei, Bucureşti, 2016.

9. Bass JD, Mulick JA. Social play skill enhancement of children with autism using peers and siblings as therapists. Wiley Periodicals, Inc. Psychol Schs, 2007.

10. McConachie H, Diggle T. Parent implemented early intervention for young children with autism spectrum disorder: a systematic review. J Eval Clin Pract. 2007;13(1):120-9.

11. Freeman S, Kasari C. Parent-child interactions in autism: Characteristics of play. Autism 2013;17(2):147-161.

12. Jung $S$, Sainato DM. Teaching play skills to young children with autism. J Intellect Dev Disabil. 2013;38(1):74-90.

13. Okimoto AM, Bundy A, Hanzlik J. Playfulness in children with and without disability: measurement and intervention. Am J Occup Ther. 2000;54(1):73-82.

14. Stanley GC, Konstantareas MM. Symbolic play in children with autism spectrum disorder. J Autism Dev Disord. 2007; 37(7):1215-23.

15. American Psychiatric Association. Manual de diagnostic şi clasificare statistică a tulburărilor mintale (DSM-5). Ed. Callisto, Bucureşti, 2016.

16. Lowe M, Costello A. Symbolic Play Test Experimental edition. Windsor: N.F.E.R., 1976.
17. Schopler E, Reichler RJ, Renner BR. The Childhood Autism Rating Scale. Los Angeles, CA: Western Psychological Services, 1988.

18. Lord C, Rutter, M, DiLavore P, Risi S. Autism Disorder Observation Schedule (ADOS), adaptat în România de David D. (coord.), 2009. Disponibil la https://www.testcentral. ro/media/ados-comanda-pdf-7OAG4Z3Y.pdf.

19. Bayley N. Bayley scales of infant and toddler development, third edition: Administration manual. San Antonio, TX: Harcourt, 2006.

20. Terman LM, Merrill MA. Stanford-Binet Intelligence Scale: Manual for the third revision, Form LM. Boston (MA): Houghton Mifflin, 1960.

21. Landreth GL. Play therapy: The art of the relationship (2nd ed.). Brunner-Routledge, 2002.

22. Păunescu C, Ene LM, Mânzat B, Popovici DV, lonescu L, Petrescu M, Niculcea D. Terapia educaţională integrată. Ed. Prohumanitate, Bucureşti, 1994. 